\title{
LANGUAGE, TRUTH AND LITERATURE ${ }^{1}$ : THE GRAMMARS OF TRUTH IN THE HISTORY OF PHILOSOPHY
}

\author{
Ph.D. Gene Fendt, \\ Albertus Magnus Professor of Philosophy \\ University of Nebraska, Kearney \\ USA \\ Email: fendtg@unk.edu
}

\begin{abstract}
Examining the history of philosophy, we can see that the word 'true' is used in many ways. These ways parallel the modes Northrop Frye saw ordered in literature. Just as his Anatomy of Criticism outlines literature's devolution from myth to romance to the high mimetic, low mimetic and ironic. We see the history of philosophy descends from mythic metaphysics to a selfdeconstructing irony. Between these we can find three asymmetrically related modes of 'being true' which exhibit the same functions and interrelations as Frye's three intermediate modes in literature. Given the work of Gödel and Tarski there is good reason to suspect that the sort of relationships pointed out by Frye and exhibited in Kant are necessary for any linguistic being. Truth is said in many ways; these ways are systematically related and allow no closure on any particular one.
\end{abstract}

Keywords: Truth, senses of; Philosophy, history of; Frye, Northrop; Grammar (Wittgenstein); Tarski, Alfred; Literary modes; Empiricism, limits of; myth; invention/discovery; language games;

\section{INTRODUCTORY REMARKS, ON GRAMMAR, TRUTH AND THE ANATOMY OF CRITICISM}

In the lecture notes Desmond Lee took from Wittgenstein in the early 1930's, which lectures were at least partly organized as comments on C. D. Broad's taxonomy of philosophical methods and systems, Lee quotes Wittgenstein as saying that "philosophy is not a choice between different "theories" for example, the correspondence, coherence, and pragmatic theories of truth.

We can say that the word ["truth"] has at least three different meanings; but it is mistaken to assume that any one of these theories can give the whole grammar of how we use the word, or endeavor to fit into a single theory cases which do not seem to agree with it. $^{2}$

\footnotetext{
${ }^{1}$ There was once a book, famous in my undergraduate years, whose author rather prided himself on solving all the major problems of philosophy in it; its title was Language, truth and logic. I mean to echo that title, if not that intent.

2 Quoted from Wittgenstein's Lectures: Cambridge, 1930-32, ed. Desmond Lee (London: Basil Blackwell, 1979) in Ray Monk, Ludwig Wittgenstein: The Duty of Genius (New York: Macmillan, 1990): 322.
} 
"What replaces theory," Ray Monk continues, "is grammar;" though what Wittgenstein means by grammar was certainly not clear to G.E. Moore at the time, and has been considerably debated since. It seems that by calling his criticisms grammatical Wittgenstein means to point out a wide variety of ways of putting sentences together using the word at issue (truth), some of which ways make them not have sense (being 'ungrammatical'). If this is the case, then his remark about truth indicates that there are at least three sorts of language game using the word truth in the philosophical traditions and while the word looks the same in every game, the distinct rules or grammar of each game in which truth gets used will generate confusion if sentences from one game are interpreted in accord with another game where the word also has a use, but a different one. Imagine using a queen from a chess set as your marker in Monopoly, or the car from your Monopoly game to replace a missing pawn from the chess set, or a missing checker; though the piece is the same, the kinds of moves each set of game rules (or grammar) allows it is quite distinct and to transfer what the piece can do from one game to another will be nonsense in the other game. This will be even more the case if we, say, use the queen as a boundary marker to play a halfboard game of checkers.

Now Wittgenstein would perhaps not like what I am going to suggest next, which is to attempt to elucidate a series of such games or grammars in a distinct relation; that relation is taken from the anatomy Northrop Frye discovered? / constructed? for criticism. ${ }^{3}$ And the question of whether Frye discovered or constructed his anatomy is analogous to the question one may ask about Wittgenstein: is his 'grammar' or 'language game' a heuristic and useful construction or a discovery about how language works? Wittgenstein for a while was puzzled in a similar manner about the foundations of mathematics: is mathematics a science where we discover or construct? Perhaps this question is ungrammatical itself where should we have to be placed, and how should we have to be in the world and the world of language, in order to (discover or, alternatively, construct) our answer to it? Could we be in any world at all? Any world we could speak about? Wittgenstein seems eventually to have answered the question about mathematics definitively (for himself): mathematics is a construction (of useful tools for physics mostly). Monk puts it somewhat differently, whatever in mathematics is presented as a discovery "should properly be seen as a grammatical (in Wittgenstein's rather odd sense of the word) innovation." "If he is right about that, then what follows should probably be regarded as the construction of a story or 'perspicuous representation' of the language games in which 'truth' can be (and has been) used. The story I will be giving is less grammatical innovation than notice of an ordering in the grammar of uses of 'truth' an order, as it were, among language games in which 'truth' is uttered. I am claiming, then, that philosophy's theories about truth are not merely different games, like Monopoly and checkers, but can be set out, at least heuristically, as an ordered relation of games or grammars.

Frye's story about literature that it orders itself as a devolution from myth to romance to the high mimetic, low mimetic and ironic seems most like a discovery in his exhibition of that devolution through history: see, the history is really like that! But that his story itself

\footnotetext{
${ }^{3}$ We should perhaps keep in mind that the Latin word invenio/invenire from which we make 'invention' meant in the first instance 'to come upon', to discover. Inventing implies our own creation: the human being and its powers make the truth of whatever is invented, say, transfinite numbers. Discovery implies the human being and its powers are already within a world not made by its own powers. In the first case the human order is mythic; in the second, the human is a more middling mimetic, as we will see.

${ }^{4}$ Monk, Duty, 468.
} 
bears readings that are at once mythic, romantic, realistic (see!) and ironic with equanimity and poise makes it again seem a (very complex) construction. It bears this plurality of significance because it has a structured openness. By this I mean that Frye's larger story allows all these different readings (from mythic to ironic) entrance and purchase on itself. This is perhaps best indicated by his beginning with a "Polemical Introduction" and ending with a "Tentative Conclusion." The mythic divine (or at least magisterial) announcement of the outline of a science of criticism is significantly tempered through the essays until we get to the ironic tentativity of the conclusion. ${ }^{5}$ It is structured in its openness to these readings in that these mythic to ironic readings are mutually implicated and run across each other in ways which deny ownership of Frye's whole story to any one of them and allow some very clear views of their mutual relations. The movement from polemic to tentativity suggests that even the most thematic of works is imbedded in a narrative arc; Frye himself here, enacts a fall from architectus to suppliant almost as if such structures are the a priori conditions of making sense in words. ${ }^{6}$ Frye suggests, besides (a) that the history of literature displays a shift in the center of gravity from the first to the last which seems a discovery, that (b) at the depths of irony we approach the mythic again, exhibiting that the pharmakon of one person is the godterm of another, ${ }^{7}$ and this circularity further suggests either (1) a dependence of the parasitic type of each mode upon the mode above it (as, perhaps, in Diotima's ladder), or (2) a more Hegelian mutual interdependence, or selfdevelopment and exfoliation of each from or within the whole, which is the body of literature. We might say of these final two options within Frye's story that in the first case everything depends upon (is parasitic on) myth as all loves are dependent upon love for the Beautiful itself, or in the second, that no one mode can be ripped from the body of the whole and taken as all in all without fatally compromising its own viability.

As is the case of the wave/quantum interpretations of the propagation of light, both these conclusions appear to be valid and each interpretation of Frye's story allows us to see some things more clearly than the other. In application to our case the problem of truth that irony approaches myth suggests that Frye's story is itself a construction: like light, one approach taken to its extreme leads to its own dialectical inversion in the form of the appearance of the necessity of the other, opposed, approach. Once we set up the problem one way, it leads determinately and necessarily to the other. The construction we begin with dictates the paradoxes that will eventually appear, and prescribe the dialectically necessary alternatives which escape those paradoxes and lead into their opposed ones. As with light and the foundations of mathematics, in Frye's case, too, it makes sense to ask how would we have to be in the world in order to grammatically phrase the foundational question: is this (story about truth or story about literature) itself a discovery or construction? What story would we already have to be in to ask such a question? In any case, it will turn out that if the story I shall be outlining is true, most of our ways of talking about truth are desiccated

\footnotetext{
${ }^{5}$ This movement from polemic to tentativity is a structural or formal sign that what I am saying is what occurs: Frye's book allows a plurality of readings. But Frye's arguments within the book also show how his story of mythic devolution runs across distinctions within the critical theory he presents in numerous places; for example, see pp. 115-117, 123-126 in Northrop Frye, Anatomy of Criticism, (Princeton: University Press, 1957). Many other lines and short segments seem to be referring obliquely to the project of the book itself and range from romantic to ironic, even sarcastic, in tone; not many authors do this kind of self-referencing.

${ }^{6}$ Frye himself does not go quite so far... at least not directly: "We have thus answered the question: are there narrative categories of literature broader than, or logically prior to, the ordinary literary genres?" (Frye, Anatomy, 162).
}

${ }^{7}$ Frye, Anatomy, 43. 
inadequacies (under 1) or meant analogously or as some kind of synecdochic reduction (under 2). At this point Frye's project would tie into that of Kenneth Burke, who considers 'the truth' according to four master tropes, which he hints are forms of reduction. ${ }^{8}$ To cash this out in the philosophical job market, the story I am outlining is a complaint that the analytic or continental, modern or medieval, postmodern or empiricist, or Platonist or feminist or Marxist idea of truth is in every case either inadequate or reductive and inevitably tied to those it denies function to. The proof follows.

\section{THE GRAMMARS OF TRUTH}

\section{A) Myth}

It is easy for philosophers to see a pattern of devolution in truth talk in our history like that given for literature in the Anatomy. Frye's first mode, the world of myth, is "a world of total metaphor, in which everything is potentially identical with everything else, as though it were all inside a single infinite body." One thinks of Socrates' myth of the Good in Republic: that which makes all things be what they are (including the knower) and be known as they are; or his myth of the Beautiful in Symposium as that in which all beautiful things bodies, souls, ideas participate and to which they all lead; that which both impregnates the soul and to which it gives birth in its speeches. It is this infinite allencompassing Eternal Idea which the demiurge in Timaeus passingly imitates in constructing the moving world in which we live, and move, and know, and imitate in our own way the Eternal Idea which the demiurge knows, and imitates. Clearly, 'myth' here is not simply a lie, nor that somewhat higher creation Hegelian picture thinking would have it be, but is the presentation of thatwithinwhichonly all questions of truth can be raised and are always already answered, awaiting only our anamnesis.

A related version is explicated in detail by any number of early Christian and medieval commentators on the opening sentences of John's Gospel: "In the beginning was the word, and the word was with God, and the word was God. He was in the beginning with God; through him all things were made and without him nothing was made which has been made" (John 1:13). It is the religion of real presence, whose time, so the story we are telling goes, is over. In it the truth of the world and of the mind and of the logos (word or thought) which the mind utters is all one: Adam names all the animals correctly, seeing them as they are because seeing them in, or through, the mind of God with whom he is intimate, naked and unashamed: "So God brought all the animals before the man and behold what he called each was its name" (Gen 2:19). Here no distinction is possible between realism, transcendentalism, objectivism, coherence, a cultural relativism of language games, or the (impossible?) individual relativism of idiolect; and pragmatism, too, is the truth of things, for in all of Eden nothing else works. Less poetically but why would we want to be less poetic? we might describe this grammar as "mythologyasframework of thought" through which we can read all of a culture's "knowledge, practices, ... modes of interrelationship..., modes of logical organization..., in a unitary manner" as Zaidman and Pantel describe myth. ${ }^{10}$ But Plato's myths (and John's and that of Genesis) are not myths for $a$ culture, but the myth of language and thought encultured everywhere: they are the myths of the relation of speaker, speech and world, and of all their possible relations.

If we were to tell this story in Kantian terms, we would have to tell a story here of a

\footnotetext{
${ }^{8}$ Kenneth Burke, A Grammar of Motives (Berkeley: University of California Press, 1969): 503-517

${ }^{9}$ Frye, Anatomy, 136.

${ }^{10}$ See Louise Bruit Zaidman and Pauline Schmitt Pantel, Religion in the Ancient Greek City, translated by Paul Cartledge (Cambridge: Cambridge University Press, 1992): 149.
} 
form of intuition which we do not have and so of which we can have "no proper knowledge:"11 we find that it is impossible to describe such a thing without driving into selfcontradiction since the ordinary language of substantives and tenses in which we tell the story seems permanently tied up with spatiotemporal intuition beyond which we are here trying to reach. ${ }^{12}$ Despite these insuperable difficulties, Kant goes on to imagine the equivalent of Frye's mythic unity of truth and being thus: "An understanding which through its selfconsciousness could supply to itself the manifold of intuition an understanding, that is to say, through whose representation the objects of the representation should at the same time exist" (B139). For this being all other being and being known are utterly, because metaphysically, coextensive: Cogito ergo est.

In more recent times, we might consider that Tolkien, Chesterton and C.S. Lewis would all probably agree with Lewis' statement that "the story of Christ is simply a true myth.... One must be content to accept it in the same way, remember that it is God's myth where the others are men's myths, i.e. the Pagan stories are God expressing Himself through the minds of poets, using such images as he found there." ${ }^{\prime 13}$ In this case it is just true, that "Chesterton's 'natural religion'... is not a deus absconditus at the end of a chain of being, but revealed and active in every phenomenon and experience." 14 The whole world and all experience of it is deeply sacramental, though most of the time we live in it like dwarves searching for porridge.

B) 'Realism': the high and low mimetic

Such a great beginning. For philosophers I think it will be easier not to follow quite exactly the narrative design of Frye's critical emplotment. The next step should be romance, but let me speak first of what Frye calls 'realism,' which includes what he calls the high and low mimetic. If "myth is an art of metaphorical identity..., realism is an art of implicit simile." "Here we can put all philosophical empiricism Locke, Berkeley, Hume and all correspondence theories of truth. According to these an idea is true insofar as it corresponds to is like the thing. So, Locke's ideas are denominated true or false "whenever the mind refers any of its ideas to anything extraneous to them" insofar as the mind's "tacit supposition of their conformity to that thing...happens to be true or false." "And "the truth of these appearances or perceptions in our minds" consists "only in their being answerable to the powers in external objects to produce ... such appearances." 17 That is to say, the ideas

\footnotetext{
${ }^{11}$ Immanuel Kant, The Critique of Pure Reason, translated by Norman Kemp Smith (London: MacMillan, 1933): B149.

${ }^{12}$ Augustine usually comes at this issue from the angle of posing a problem of the bounds of language rather than as a bound of epistemology; he regularly presses language to the point where it breaks down and must fall silent (e.g., Confessions 1.4.4, 9.10.23-26). Nonetheless, he continues to speak. Undoubtedly these two angles are complementary, for whereof we cannot speak, thereof we seem not to be able to remain silent, or as Kant puts it the "extension of concepts beyond our sensible intuition is of no advantage to us. For as concepts of objects they are empty, and do not even enable us to judge of their objects whether or not they are possible" (B148). Here Kant must mean of no advantage to our knowledge of things, for he has, nonetheless, already used one such concept (the creative intuition), precisely to exhibit the bounds of our knowledge.

${ }^{13}$ Bradley J. Birzer, J.R.R. Tolkien's Sanctifying Myth: Understanding Middle Earth (Washington: ISI Books, 2003): p. 26.

${ }^{14}$ Alison Milbank, Chesterton and Tolkien as Theologians: The Fantasy of the Real (London: T and T Clark: 2007), p. 11.

${ }^{15}$ Frye, Anatomy, 136.

${ }^{16}$ John Locke, An Essay Concerning Human Understanding, Book 2, chapter 23, paragraph 4. I have used the edition of Alexander Campbell Fraser (New York: Dover, 1959).

${ }^{17}$ Locke, Essay, Book 2, chapter 32, paragraph 16.
} 
imply nothing about the substance of the thing being, for example, actually blue or bitter, just that it looks or tastes like that. In fact, Locke goes so far as to say of our ideas of substances that "they are all false, when looked upon as representations of the unknown essences of things:" ${ }^{18}$ we do not grasp the essence, but something relative. Similarly for Hume, impressions are our more lively perceptions; ideas the less lively perceptions of which we are conscious when we reflect on the first. "Every idea is copied from a similar impression." 19

One can translate this theory of psychological simile into one about truthfunctional propositions and avoid the direct psychologistic problems brought to bear upon the early empiricists. This is, in fact, how presentday empiricism is related to those earlier versions. In this case, 'truth' indicates the degree of likeness between the proposition and the world; e.g., 'snow is white' is true, if and only if snow is white. In the former case, that of empiricist psychology, we have degrees of likeness between the more or less rapidly fading idea and the more vivacious impression. In the latter case we have: "The world is everything that is the case" and "the world is the totality of facts not things" and "a proposition is a picture of reality" and "the totality of propositions is a language" as a fairly good summary of the logic of the position. ${ }^{20}$ If all of your propositions are like the world, you're in good shape. Somewhat more formally we might say, "If it is true that $p$, then, in so far as it can be known that $p$, someone can believe that $p$ precisely because $p$." Thus runs the helpful patter of present day empiricists. ${ }^{21}$ Under such empiricism and positivism, moral and aesthetic truth must (just as everything else) correspond to something $=p$, and so we have to go about looking for what it is. Hobbes and Hume as well as many more modern thinkers judge it to be certain sentiments, which they are (variously) willing to call socially influenced/shaped/created. In the Tractatus, Wittgenstein says morality and aesthetics lie outside the world, whatever that means if the world is everything that is the case. What it means, I am given to understand, is that the shape of the world is moral or aesthetic. But this wordshape seems as a simile without a correlate, unless that correlate is feeling, sentiment, passion. According to Hume and his children these feelings are clearly things in the world, so if Wittgenstein is not agreeing with Hume we must begin to think that this simile without a correlate is a sign of the deracination of the early Wittgenstein's story about language and truth from a more complete and perfect world in which it can grow and have its place. ${ }^{22} \mathrm{We}$ should not be surprised to discover that the plant quickly desiccates, and Wittgenstein himself moves back to a more rooted story of how language achieves truth. Perhaps, in fact, that was his aim all along in the Tractatus to show the inadequacy of such empiricist and positivist views by strict entailment all the way out to the point where they can be seen to have no possibility of saying anything. Yet we speak of such things: Michelangelo's David is sublime.

So, in fact, we do not have to think that Wittgenstein believed his Tractatus story about language, truth and logic to be true tout court. He could have been making a sort of

\footnotetext{
${ }^{18}$ Locke, Essay, Book 2, chapter 32, paragraph 18, cf. paragraph 5.

${ }^{19}$ David Hume, An Enquiry Concerning Human Understanding, Section 2, paragraph 14; see also paragraph 12. I have used the edition of P. H. Nidditch and L. A. Selby-Bigge (Oxford: Clarendon, 1975).

${ }^{20}$ See Ludwig Wittgenstein, Tractatus Logico-Philosophiccus, translated by D. F. Pears and B. F. McGuinness (London: Routledge \& Kegan Paul, 1961), sentences 1, 1.1, 4.01, 4.001.

${ }^{21}$ See, for this example, David Wiggins, "Objective and Subjective in Ethics, with Two Postscripts about Truth" in Needs, Values, Truth: essays in the philosophy of value (New York: Blackwell, 1987): p. 35

${ }^{22}$ See David Rozema, “Tractatus Logico-Philosophicus: A 'poem' by Ludwig Wittgenstein,” Journal of the History of Ideas Vol. 23 No. 2 (April 2002): 345-363.
} 
poem to illustrate, or perhaps imitate, the deracination and essential moral vapidity of that contemporary empiricist and positivist view of the world. It is true and accurate about that (about which it says nothing as required). This would mean that the socalled turn in Wittgenstein's thought would not be a real turn, but that his first book was a tract exhibiting what the reduction of philosophy to logic would really amount to, leaving it to the reader to throw away the ladder that gets one into such an inhuman and unlivable position. The later works would then be different attempts at curing similar sorts of problems, exhibiting their ungrammaticality if not their unliveability. On either reading of Wittgenstein, we could understand the idea that mathematics needs a foundation as of a piece with the Tractatus view of language, and Wittgenstein moves away from both that idea of mathematics and the Tractatus view of language toward the idea of grammars, rules, and language games making sense in ways of life all at once.

G. E. Moore, around the same time, attempts to answer the empiricist problem about moral and aesthetic truth. He thinks he has found what our terms correspond to (at least for ethics, though not aesthetics) — a simple nonnatural indefinable and nonanalyzable quality ${ }^{23}$ which requires a special capacity of mind he calls intuition. We should note how Moore's view approaches here the mythic version of truth we saw in Plato, who would have called intuition nous, but who has a much richer story to tell about it than Prof. Moore who really has only the word. We should now be drawn to remember that, according to Plato's myths, we were said to have seen or experienced the Good, the Beautiful, and those other eternal things beyond the rim of heaven in our previous lives, as we drove our human and imperfect chariots behind those of our chosen god. ${ }^{24}$ In that world was everything that is the case; now we are in the world of resemblances and moving images; the world of likeness. So the truth of empiricism is one aspect of the original mythic truth, empiricism is both held up by and holds up (could we but recollect the experience) that mythic world which (and in which) it hides; nous gets us back there through recollection.

Heidegger restates this point when he emphasizes that the correctness sought in epistemê hides, or is forgetful of, the truth of Being, in its concentration on beings. Poetry is aletheic, it brings that openness to Being back before us, perhaps even through the thing the poet concentrates on: old shoes, for instance. Heidegger is closer to Plato than Moore in that he seems aware that the pressure for epistemic exactness about a thing or relation requires $a$ forgetfulness of that in which it appears. Moore rather aims to identify yet another form of epistemic exactness, and thinks thereby to bring both truth and completeness to our thinking. At least Moore recognizes something is amiss in empiricism as it stands, that he needs something more. Empiricism needs a supplement; Moore calls that supplement intuition, Heidegger calls it poetry, Frye suggests that both need a myth in which to hang. As in Frye's 'world of total metaphor,' so also in Plato's Timeaeus vision of the allencompassing Eternity, or Republic's untold story of the Good itself: in the mythic world empiricism is also true, and only within such a mythic world can such realism be understood as truth.

A short parable: In the Future of an Illusion Sigmund Freud tells a story of his young son hearing a fairy tale from his governess and, upon asking "but is it true?" and being told it was not, walking away in disgust. ${ }^{25}$ Freud considers this an exhibition of admirable sentiment on the boy's part. Just so, we might expect Freud's contemporary sons will ask of

\footnotetext{
${ }^{23}$ G. E. Moore, Principia Ethica (Cambridge: Cambridge University Press, 1903), chapter 1.

${ }^{24}$ See Phaedrus 245c-257b and Meno 81.

${ }^{25}$ Sigmund Freud, The Future of an Illusion, translated by W.D. Robson-Scott, revised by James Strachey (Garden City, NY: Anchor Books, 1964): chapter 5.
} 
Whitman's answer about the grass that same deracinate question: "but is it true?" and when they find out that it is not "the case" they will, like other positivists, turn their back on literature in toto. Given the limiting strictures put on truth by empiricism, this response is entirely proper, but (dare we ask?) are those strictures true? Freud himself was not quite so dismissive of literature as he appears in this story, or as the Vienna Circle was in reality, but that is only because the good doctor believed that much of literature was true in the historical sense of referring to events either in the deep past of the original totemic clan, or in the mists of infantile ego formation: "the Lord's handkerchief?"no; "the uncut hair of graves?"if we understand it as the blooming of the death principle, yes. ${ }^{26}$ Faith in that myth being lost, literature can carry no truth value whatsoever: "commit it, then, to the flames for it can contain nothing but sophistry and illusion." 27

Returning to our overarching story, we might be able to distinguish Frye's high mimetic from low mimetic realism in philosophy of mind by paying attention to the status of the mind in each case. So, for example, Aristotle and the medieval realists (e.g., Aquinas) who followed his lead, thinking that the mind abstracts the knowable essence from the thing, gave the mind thereby "a power of action somewhat higher than the environment" 28 of things in which the mind dwells and which things act upon the mind and which the mind thereby knows. The empiricists who come later are low mimetic (Locke, Hume, et al.); the mind is like a piece of wax; things leave their impression on it, these impressions are ideas. Things happen; the mind accepts them. The things that happen are connected by contiguity or constant conjunction; we are in the habit of calling such repeated conjunctions 'causality'. The patterns repeated more frequently delve deeper furrows into the waxy tablature of the mind than singularities. Gradgrind does this to Bitzer (who at the end of the novel is capable only of these little bits of empirical truth) quite successfully. Reality is gradgrind: it gradually grinds our mind into agreement with itself. ${ }^{29}$ Occasionally, damage (for example, after leaving by the window rather than the door once too often) or disease (fever) causes a meltdown of the wax. The mind is "not a significantly different kind of thing from the environment," nor does it have any more significant powers than the usual wax. This is precisely Frye's description of the low mimetic; one wonders if such a thing can be any kind of hero. ${ }^{30}$

Wittgenstein's comment about A.J. Ayer after the radio debate with Fr. Copleston can be well understood from the contextualization we are giving here: Wittgenstein said that Ayer "has something to say, but is incredibly shallow." 31 Ayer is demanding that the rules for words like true, objective, exists, etc. stay within the well known game of low mimetic empirical science; he has something to say in pointing out when Copleston is speaking ungrammatically according to the low mimetic game Ayer considers these words belong to. So Copleston contributes "nothing at all to the discussion" because he does not notice that he himself is using these words in accord with a different language game, but takes them over

\footnotetext{
${ }^{26}$ The quotes here are from Walt Whitman's "Song of Myself," part six; this part begins with the child's question "What is the grass?" Available online at https://www.poetryfoundation.org/poems/45477/song-ofmyself-1892-version .

${ }^{27}$ This is David Hume's suggestion for the improvement of libraries; see his Inquiry, section 12 part 3; this is the last sentence of his Inquiry Concerning Human Understanding.

${ }^{28}$ Cf. Frye, Anatomy, 33-34.

${ }^{29}$ See Charles Dickens, Hard Times.

${ }^{30} \mathrm{Cf}$. Frye, Anatomy, 34.

${ }^{31}$ Monk, Genius, 543; quoting Rush Rhees, ed., Recollections of Wittgenstein (Oxford: Oxford University Press, 1984).
} 
from the low mimetic game of Ayer as if there were no important differences between speaking of the truth of God's existence and the truth of the existence of a bowling ball, or the truth that grass is green and snow white.

The grammar of low mimetic morals is similarly reductive: judgment becomes the mobile expressionistic result of a congeries of variously graven inputs pleasure, pain, survival, parental or social dissatisfaction, etc.: were our empirical science perfect, morals would be as predictable as a machine: ouch. That is the point of Bitzer's transformation by Gradgrind; in the end Gradgrind feels the pinch of his own exact machining. Perhaps the mythic command against graven images can yet be understood even at this low mimetic level? The point of the Dickensian work of art is to make us feel not only the pain, but more the injustice and reductive partiality of such a world. This is precisely what makes it comic. The novel makes a world in which empiricism is the whole truth; but that world is seen (by us in the audience) not to be true: people aren't all the way like that, really. At least Dickens seemed to think there were other possibilities. We can, however, only feel this world as reductive, partial, unjust and so painful or mocking because we feelingly know that world of total and complete empiricism not to be the world though it is like the world.

This exact reductivism is exhibited by some contemporary thinkers. Take, for example, Barbara Herrnstein Smith, whose "alternative view of [the] matter" regarding both moral and aesthetic value (and, it turns out, much else) is explained thus: ${ }^{32}$ She sets out a view of the individual human being (if I may use the phrase) as an algorithm for particular evaluations. The algorithm is built up by the usual inputs, which, because they can vary through life, make the algorithm vary. Each evaluation comes as the solution to a multivariable equation of innumerable variables; she gives a list of the kinds of variables, but could never list all of them. The list of evaluative outcomes is a similarly variable range of more and less articulate grunts (or clicks or swipes) of approval and disapprobation, "most of which", she says, "are performed intuitively and inarticulately, and many of them so recurrent that the habitual arithmetic becomes part of our personality and comprises the very style of our behavior." 33 She thinks that the great advantage of this alternative view is its reductivism; as she says, "in accord with such an account, evaluative divergences and the exhibition of socalled bad taste would be seen as the product of the same dynamics the playing out of the same kinds of variables, but with different specific values that produce evaluative convergences and the exhibition of socalled good taste." And this alternative view can be played out with regard to all human preferences, from art to food, from sex to religion, "or even [to] types of logic." ${ }^{34}$ Of course, in this view good and bad taste are just algorithmic outputs of approval or disapprobation of each other algorithm's outputs of disapprobation and approval; there is no correcting of algorithms. Some algorithms complete their circuits positively due to a shaken box of glass punctuated unrhythmically by gunshots, some turn on for Bach; "good taste" is a phrase for communal agreement in algorithmic output.

We recognize this merely the return of low mimetic morals in a more modern dress, designed to fit with the sharp modern sensibilities of mathematics and computer programming. Of our last few centuries' history, then, Moore should be considered the high mimetic version of the generally low mimetic British Moral Theorist. His requirement of a

\footnotetext{
${ }^{32}$ Barbara Herrnstein Smith, Contingencies of Value: alternative perspectives for critical theory (Cambridge: Harvard University Press, 1988): 38.

${ }^{33}$ Ibid., 43.

${ }^{34}$ Ibid., 39 and 43.
} 
higher power of the mind was of a piece with this; venturing into personal psychology I should guess that he was raised as a High Church Anglican almost as High Church as Aquinas. Hume, if my memory serves correctly, was Presbyterian, and he abandoned it. Smith indubitably joins him in the low mimetic if she is not already speaking from the ironic world, for her protagonist self seems already a mere "scene of bondage." 35

\section{C) Romance}

"Myth, then, is one extreme...; naturalism is the other, and in between lies the whole area of romance, using that term to mean...the tendency...to displace myth in a human direction and yet, in contrast to 'realism,' to conventionalize content in an idealized direction." 36 The best example of this kind of story about truth is Kant, whose introduction to the Prolegomena and preface to the first edition of the Critique of Pure Reason read like romances: in which the knight of honor goes forth to redeem the name of that slandered queen, Metaphysica.

Time was when metaphysics was entitled the Queen of all the sciences; and if the will be taken for the deed, the preeminent importance of her accepted tasks gives her every right to this honour. Now, however, the changed fashion of the time brings her only scorn; a matron outcast and forsaken, she mourns like Hecuba. ${ }^{37}$

Kant goes on to argue that the science which the empiricists think gets at all the truth that there is (empirical realism) depends essentially on a truth it never achieves or can achieve what Kant calls the regulative ideals of pure reason. These ideals are at work in each and every effort of empirical science; exhibiting their necessity and becoming perspicuous about their nature is the effort of the first Critique, and that book shows how all of our ordinary truths about snow are part of an idealized and ever incomplete project of reason: the complete Naturwissenschaft of the never wholly intuited cosmos of Nature. Kant hints early and argues later that this project (science) is essentially moral, ${ }^{38}$ for the empiricalrealist science which gets at nature's truth depends upon the same autonomy of reason which produces the categorical imperative, and the moral law which is the engine of the whole (to bring things down to a low mimetic machinist's analogue) has the purity and autonomy of the true queen, whom we all love and have loved always. Reason in this moral sense extends further than intuition, which in Kant is already a higher power than mere empiricist sense perception, and reason has freedom autonomy from the causal rules of sense; and it must have this or we could not unify our experience or form hypotheses and "constrain nature to answer" as empirical science does.

The selfgrounding and selfrevealing God of the mythic world is thereby displaced in Kant to practical reason (displacing myth in a human direction, as Frye says), which proves both its existence and its right by deducing its law a priori, refusing any aid from empirical anthropology. Nor does this mind merely abstract from its experience (as the high mimetic mind), rather reason directs the investigation of, and action in, the empirical world in accord with its own regulative ideals in a language whose syntax is underwritten by the a priori synthetic truths we lay out in mathematics, and the metaphysics of nature and of morals. Far from being a piece of wax, this mind is one with nearly demiurgic powers. Perhaps this

\footnotetext{
${ }^{35}$ Frye, Anatomy, 34.

${ }^{36}$ Frye, Anatomy, 137.

${ }^{37}$ Immanuel Kant, The Critique of Pure Reason, translated by Norman Kemp Smith (London: MacMillan, 1933): p. Aviii.

${ }^{38}$ Cf. Gene Fendt, "De Reductione Scientiae ad Bonos Mores" in For What May I Hope: Thinking with Kant and Kierkegaard (New York: Peter Lang, 1990): pp. 45-71.
} 
mind is Plato's demiurge; to say so would be to (speaking as a literary critic) demythologize Plato into what Frye would recognize as the romance of Kant.

We must be particularly clear that the truths of morals are not, according to this romance, discoverable in the way that truths about snow and the rest of the physical world are, for they cannot appear in intuition, not even intuition of one's own moral action. Nonetheless, the truths about snow and the world depend upon (what Kant himself calls) the fact (not just the possibility) of moral truth, in particular, that moral truth called freedom. ${ }^{39}$ The word 'fact' here also participates in the romantic phase of language rather than low mimetic grammar of empiricism. The truth here is not discovered through an intuition of a thing, still less is it an idea decaying from such an intuition, rather this truth is itself an unituitable active power: we could not discover any (low mimetic empirical) truths were reason not truly the (romantic) power of making laws for itself. Kant is, then, a moral realist, but what counts as real is not objective in the way that what counts as real in empirical science is objective: 'objective' too has distinctive uses in the romantic grammar. Further, we see that these senses of truth in Kant's philosophy are a mimesis of the hierarchical organization of the types of hero we find in low mimetic, high mimetic and romantic literature.

Kant is very clear that these two kinds of truth (which we are calling romantic and realist) are not merely different; they are related in an asymmetrical way: the objectivity or realism of the moral realm is the condition for the possibility of the discovery of any real truths about nature; but the reverse is not true. Further, the fact of freedom presupposes the coherence of reason's unintuitable autonomy with the discovery of truths about nature, but that coherence does not prove the fact of freedom either. You can't get from nature to freedom; you must already be free to come to know nature at all. Aesthetic judgments are a third kind of truth, but they, too, would not be possible without the fact of morality; their 'objectivity' takes yet another form, one which not only coheres with the other two, but in addition is the ground or condition for any actual community among human beings in the world of experience, for only if feeling, intuition and intellect are connected in the same way in all of us can we even speak to each other, much less come to agreement about any political or aesthetic or even empirical issue.

Kant's transcendental arguments about the work of reason both perform and defend that 'romantic' (in Frye's sense) "power exceeding that of ordinary sense and the environment" which belongs to such high heroes, and we have seen does not belong to an empiricist mind. Kant's Reason, like the hero of romance, has a power of operation "superior in degree" to both the mere empirical understanding and to its environment. This power, unnatural to empirical understanding and intuition but natural to practical reason, and coherent with low mimetic truths about snow places the human being at once in the world of experience and in the supersensible world of morality. Freedom is a "magic mirror," an "enchanted weapon" if ever there was one. ${ }^{40}$ In fact, it is the source of all such stories. The truth of romantic fairy tales is their aletheic revelation of the moral power and the higherthantheenvironment status of all moral soul.

D) The ironic

Descending below the high and low mimetic with which we have already dealt, we

\footnotetext{
${ }^{39}$ See "On the Primacy of Pure Practical Reason in its Association with Speculative Reason" in The Critique of Practical Reason, translated by Lewis White Beck (Indianapolis: LLA, 1956).

${ }^{40} \mathrm{Cf}$. Frye, Anatomy, 33 for all of the phrases in quotes in this paragraph; they are signs that we are in a romantic phase.
} 
find the ironic mode, which "begins with realism and tends toward myth, its mythical patterns as a rule being more suggestive of the demonic than of the apocalyptic."41 Here the division of the original mythic body of truth becomes absolute: each element is a windowless monad whose vision of what is is entirely its own. Each vision may be coherent in itselfeach has its algorithm, we might say but thoroughly different from each other vision. Without a God to guarantee their preestablished harmony, each will be constructing, or showing, its own selfmade film: each is its own private theatre of "true to me." One may, at this point of anomic despair, be tempted to invoke an argument against private language (Wittgenstein), or voice a prayer for solidarity amidst all these contingent ironies (Rorty), or attempt to demonstrate that the grinding gears of natural selection delete those running peculiar (let us not call them queer or avantgarde) films (Spencer, and his more welldressed grandchild, Sociobiology). But can such invocations be thought to go somewhere? I ask myself. Each of these later figures thereby exhibit what they would have take the place of Leibniz's more romantic version of God: language (high mimetic), groundless solidarity (low mimetic), natural selection (ironic). But to ask which is true, or whether any of them are so, is to take us immediately out of irony, for asking the question pretends that other monads hear and they (might) care. I say to myself.

No ironic form will close the option that it may well be that no other monad is sharing my film or that in any case one is merely applauding a universality that appears only in one's own private theatre. And it can't; I am tempted to ask for the condition of this impossibility, but that is (according to it) to be tempted by Metaphysics, which is impossible. In this story any agreement among monads (how would we notice it?) is purely contingent; there is no queen, and certainly no God preestablishing our harmony. This space is where the purely coherentist notion of truth operates and in its smallest space. Further, what counts as coherent may vary widely (how could we tell?) if, as some literary theorists in this mode hold "even [our] types of logic" are merely a convergence of our own particular preferences. ${ }^{42}$ Barring the pragmatism of the boxcutter and the bomb, it will only be by some totally mystifying supervenient grace (mythic explanation), some invisible hand (a high mimetic explanation), that these monads will come to agreement about the truth of either things or of values: without such (variably interpretable) grace the divisions between individuals are infinite and unbridgeable each is a differend to the other. ${ }^{43}$ Lyotard's position seems to me to be the French (or continental philosophical) version of one espoused by (the more analytic) Gilbert Harmon; he allows that there "is even the limiting case ... [of] a oneperson group" determining the ethical good. ${ }^{44}$ But such a differend is undiscoverable; such a one has no common language or way to share his experience with us thus Lyotard must begin his book in the passive voice. How such a thing (as the differend) can become known to us is precisely the mystery that can't be answered under this view. There can be no subject speaking to another subject; the death of the subject is the bottomless end of this phase. ${ }^{45}$ We do not find ourselves to be quite in this position yet. (How could we. find. it. to be?) There is a similar solipsism implicit in pragmatism that is exactly its problem with

\footnotetext{
${ }^{41}$ Frye, Anatomy, 140.

${ }^{42}$ Smith, Contingencies, p. 39.

${ }^{43}$ Jean-Francois Lyotard, The differend: Phrases in Dispute (Minneapolis: University of Minnesota Press, 1988): p. xi.

${ }^{44}$ Gilbert Harmon, Moral Relativism and Moral Objectivity (Oxford: Blackwell, 1996): p. 7

${ }^{45}$ Achieved by Roland Barthes, "The Death of the Author," in Image, Music, Text, translated by Stephen Heath (New York: Hill and Wang, 1977): pp. 142-148.
} 
regard to truth. As the always witty and inevitably trenchant Santayana once said, pragmatism seems "to express an acute critical conscience, a sort of will not to believe; not to believe, I mean, more than is absolutely necessary for solipsistic practice." 46

We cannot find this situation out; and, to speak as mere empiricists, we don't. Irony, even to be understood, requires a lighting it cannot supply itself. So, supervenient grace is operative: QED. This grace is present everywhere; it is that by which we see the ironic smile to be ironic and a smile or, not a smile perhaps. The term grace is, however, completely blank to irony, its emptiness repeating a movement seen in (Moore's) empiricism under the term intuition. We have now returned to myth, as Frye said we would, though coming to it this way and from this direction makes grace and sacrament seem Absolutely Other (totaliter aliter, as some later Medievals would put it) to each and all of us: totally transcendent to our profane world(s), yet we are somehow open to it.

So far then, we can see that Frye's claims about the five modes, as well as his claim that irony approaches myth, do play out in the anatomy of truthgrammars in philosophy as well as they did in literature.

\section{LOGIC AS TROPE}

There is a formal analogy to this story about truth. It is, I think, more than an analogy; more like the keystone of the arch which joins philosophy (and its history) to literature (and its history), stone across from like stone, in these devolutionary histories. In 1931 Kurt Gödel published an important paper on undecidability in formal systems, which proved that in any formal system adequate to number theory there is a formula that is not provable and whose negation is not provable. In other words, the consistency of a formal system can not be proved within that system. Alternatively, if consistency can be proven, completeness cannot be. What we have seen in our examination of truth is the playing out of that claim about formal systems in the very informal and unaxiomatized system of ordinary language. Gödel's proof showed that mathematics could not be proven both complete and consistent within the bounds of one formal system, that the consistency of a system can only be proven by taking a step outside that system into another and if that second can be proven to be consistent we will not be able to prove its completeness.

Almost as a proof of this, Alfred Tarski, in the course of his argument in "The Semantic Conception of Truth," notes that while his reasoning is very closely related to that used by Gödel, it "may be added that Gödel was clearly guided in his proof by certain intuitive considerations regarding the notion of truth, although this does not occur in the proof explicitly." ${ }^{47}$ In other words, Tarski holds that Gödel's reasoning about formal systems (which inspiration Tarski is following) can itself be seen to depend upon and be involved in Tarski's larger and more general theory about truth in semantic systems: Gödel's truths about the formal system of mathematics are imbedded in the metalanguage of language and his proof mimics Tarski's thought, as Tarski proves it must (even though Gödel's work was published first). Tarski's claim in this footnote is for the structural necessity of a certain nesting of languages in our ways of using the word 'true'; Gödel was merely playing that out (ahead of time) in the limited area of number theory. There is, perhaps, an analogue of these semantic and mathematical problems in physics, if the cosmos does not support a physics without a singularity precisely a point which extends beyond the limit of physics: a point

\footnotetext{
${ }^{46}$ See George Santayana, Winds of Doctrine: Studies in Contemporary Opinion (New York: Scribner's, 1913): p. 130.

${ }^{47}$ Alfred Tarski, "The Semantic Conception of Truth and the Foundations of Semantics" in The Nature of Truth, edited by Michael P. Lynch (Cambridge: MIT Press, 2001): p. 360 n18.
} 
where the physics breaks down. For my part, I would like to say that Frye was clearly guided in his Anatomy by certain intuitive considerations regarding the notion of truth, although this does not occur in his anatomy explicitly. In other words, Frye's analysis allows us to produce a perspicuous representation of the variety of grammars in which words like 'true,' 'objective' and 'fact' are used, and this clearly guided his intuitions about literature, though a discussion of the grammars of truth does not appear explicitly in his anatomy. We have now explicated that fact.

We should further point out that Tarski himself restricted his notion of truth to semantically open artificial languages languages whose semantic predicates (predicates like 'true') apply only to sentences of languages other than itself. This requires the nesting of an object language within a metalanguage in which those predicates may apply (and which in turn must also be semantically open to a metalanguage in which its truth may be expressed...). Our story is clearly related to this kind of logical vision of one complete system depending, for proof of its consistency, on something not provable within it, and that next system depending, for proof of its completeness, on something outside that, and so on. To start at the bottom, any ironist's view is perfectly consistent in itself, but he wishes to talk to someone about it and even convince them to be in solidarity with him; the accomplishment of that task requires a step outside his 'object' language, and his language game. A pragmatist ironist (Rorty, to name names) wishes to make all such accomplishment nonlinguistic and so avoid this logical problem. With the right tools (including boxcutters and bombs) I suppose that it is possible to accomplish this in the pragmatic sort of way which reduces those who disagree to dusty silence. Kant once suggested that this might be the only sense to "perpetual peace." He was, I think, being ironic, since he clearly argues that there are "facts," "truths," even "objective truths" that reason can grasp which are beyond pragmatist and empiricist uses of such words, but not beyond such a rational being's ken. Even a pragmatist can see the outside of the grammar he has been organizing: "a rule of thinking which would absolutely prevent me from acknowledging certain kinds of truth if those kinds of truth were really there, would be an irrational rule."48

Kant perspicuously unites the next three higher versions of truth, for he shows that while Hume's low mimetic empiricism is perfectly consistent, it is incomplete: it cannot explain the condition for its own possibility (much less that of mathematics). For that a transcendental argument is needed. That first transcendental argument shows how the waxmind must be structured in order to do the things it does (i.e., that it must be something more than mere wax) and so involves us in a system that includes freedom, a fact the proof of which lies outside the system of empirical science as well as beyond that first deduction, though it can be shown to be wholly consistent with the low mimetic empirical science. A second (and second kind of) transcendental argument is needed to prove the fact of freedom, and that argument has implications which take us beyond the high mimetic story of a mind which asks questions of nature into the romantic truth of freedom's relation to sensibility. That Romanticism followed Kant's third Critique is simply a fact of cultural history, which might prove something to an empiricist, if she thought history was a science and could prove something.

But however neatly this story and analogy work, natural language is not a formal system (as Tarski admitted), and so I conclude that all of these modes of truth are always

${ }^{48}$ William James, "The Will to Believe," in The Will to Believe, Human Immortality, and Other Essays on Popular Philosophy, (Mineola, NY: Dover Books, 1956): 28. 
operative in it, and variously deployed by its users, in one great glass bead game. Though we might be able to see distinct plausible ways of using the word 'true', what we might have wished to believe were separate language games cannot really be separated in vivo. And as to the question of whether this entire game is dependent upon some extramythic origin (In the beginning, when God made...) or is the exfoliation of language itself (There is nothing outside of the text), I propose that that question is undecidable from within that informal system we have and in which we move, and therefore we have stories which go each way. This, then, has been a logical proof. Frye suggests, in numerous places, that the devolution from myth to irony which provides his anatomical outline is echoed in various societies, and at least in various communities of readers; thus in an ironic age a mythic allencompassing work will be hooted at like an old tale; a low mimetic age, on the other hand, would have to accept such a prediction of reception theory to be a proof of truth, if, in fact, such a reception occurred. A more mythic community of readers would accept it, as day brings the news to day and night to night imparts wisdom, or as one Overman on his mountaintop shouts to the next, over the clouds and the alltoohuman valley.

But perhaps we should return to what Kant said beginning his first Critique: "Human reason has this peculiar fate that in one species of its knowledge it is burdened by questions which, as prescribed by the very nature of reason itself, it is not able to ignore, but which, as transcending all its powers, it is also unable to answer." ${ }^{49}$ As mathematics proves to be essentially tied up with our language and way of understanding, this undecidability will remain a permanent issue in the question of its foundations as well. There will be mythic mathematical Platonists, like Cantor, who will say they are discovering new worlds of intellectables; there will be low mimetic engineers, like Wittgenstein, who say the mathematician is just shaping a useful tool though he may not know what it is useful for yet. I do not mean to be heard as saying that such questions (about mathematics or the senses of truth) are essentially undecidable, only that they are so for us. I mean to recall two technical notions in this last sentence. First, according to Tarski, a theory is essentially undecidable if all consistent extensions of it are undecidable. ${ }^{50}$ Second, according to Aquinas, recall that what is supremely knowable in itself, may not be so to a particular intellect-i.e., for us. ${ }^{51}$ For the sake of completeness, let me add the testimony of science fiction. In Imaginary Magnitude, the higher artificial intelligence of GOLEM (originally a defense department project) concludes its final lecture to lower human intellects by confessing to a limit to its own knowledge, and then adds, "one ought to set limits, not only to the subject being examined, but to one's own speculation as well, so as not to become totally arbitrary." ${ }^{52}$

\section{SOME CONCLUSIONS FOR TEACHERS}

I have therefore found it necessary to practice irony, in order to make room for faith. attributed to Louis Mackey

Does it matter whether Louis Mackey ever said this? Given the ordered partiality of all of our ways of talking about truth, what does it mean not to have an ironic tinge to one's teaching or writing? For the human being who pretends to mythic wholeness (or even completeness and consistency) is delusional. God might be able to teach so; or Adam speak so before the Fall; but mustn't the rest be megalomaniac selfspeaking myths? Such

\footnotetext{
${ }^{49}$ Kant, Critique of Pure Reason, p. Avii.

${ }^{50}$ Undecidable Theories, (Amsterdam: North Holland Publishing Co., 1953), Preface.

${ }^{51}$ Thomas Aquinas, Summa Theologiae (New York: Benziger Brothers, 1947). 1. q. 12, art. 1; cf. 1.2.1.

${ }^{52}$ Stanislaw Lem, Imaginary Magnitude, translated by Marc E. Heine (New York: Harcourt Brace Jovanovich, 1981): p. 243.
} 
apocalyptic tones, such presumptions of completeness and coherence what else can be made of them? Kant's way of writing seems to lack irony until one considers...how ironic is it for a philosopher to "find it necessary to deny knowledge?",53

So let us, finally, follow Kant to a more medieval conclusion. Kant shows that the truth of empiricism depends upon something beyond it: a principle not provable within its system the freedom of reason. We might say that the language of empirical science is (necessarily) semantically open to that of morality. So, too, it will turn out that morality depends for its completion, and the coherence of our moral actions in a complete system, upon a principle outside itself: the existence of God (and ourselves) in the realm of ends: a kingdom of ends, a community of justice. And that we can consider these options and their beauty (or lack thereof) together depends on a fact that even the fact of freedom does not guarantee or prove: that sensibility and reason work harmoniously and alike in all of us. But this fact can't be proven either empirically or as the categorical imperative (which proves the fact of freedom). Take the first: the existence of God cannot be proven within morality, but God and immortality are implicated in every moral act; we might say that the language of morality is (necessarily) semantically open to faith. To Kant this necessary openness seems to require faith, as his discussion of Spinoza makes clear. ${ }^{54}$ In making his moral argument for the existence of God, Kant is merely proleptically affirming the same thing that Gödel stated: that the undecidable formula, s, of a formal system is presumed true. In any case, it is logically and naturally impossible to close the language of the moral world upon itself; and this is true of every other lower grammar employing the word truth as well: it is not closed any presumptions of completeness and coherence are false.

I suppose, however, the semantic openness of morality to faith really means something further: that it is necessarily possible that God could 'speak' to man, and that if He chose to do so he could make himself understood, through some analogy available to us: There could be a Word outside our words with which all our natural language is coherent and from which all our language's truth functionality can be judged. So, we could be found to be true or false. One thing further; having heard and understood, to know that Word as true would require that we have a further openness, but I think that that further openness must be something other than a mere semantic openness of language to God's word, and more plausibly called a metaphysical openness of our being to some kind of unity with the God through that Word, some kind of what Aquinas calls "being made deiform." ${ }^{55}$ Quite naturally, and quite in keeping with the logic of truth in natural language, I cannot argue in proof of this principle, but I may consistently pray that this Word be done unto me. Pragmatically speaking, it is the one true thing to do. Perhaps then, irony isn't a sin, as Mackey used to point out was Aquinas' position; perhaps, sed contra, it is a practice of prayer. And prayer is the real solidarity of the human race in its true city, where lesser ironists (or more megalomaniacal ones) attempt a solidarity which is merely a response to a force they dislike. ${ }^{56}$

\footnotetext{
${ }^{53}$ Kant, Critique of Pure Reason, p. Bxxx.

${ }^{54}$ See Immanuel Kant, Critique of Judgment, KU $452 \mathrm{f}$.

${ }^{55}$ Thomas Aquinas, Summa Theologiae 1, q. 12, art. 5, 6.

${ }^{56}$ Earlier versions of this paper were given as part of an NEH seminar on Literature and Values at The University of North Carolina in the summer of 2001, and at a conference in honor of Louis Mackey at the University of Texas, Austin in the fall of 2005.
} 


\section{BIBLIOGRAPHY:}

[1] Aquinas, Thomas. Summa Theologiae. Translated by the Fathers of the English Dominican Province. New York: Benziger Bros., 1947.

[2] Birzer, Bradley J. J.R.R. Tolkien's Sanctifying Myth: Understanding Middle Earth. Washington DC: ISI Books, 2003.

[3] Burke, Kenneth Kenneth. A Grammar of Motives. Berkeley: University of California Press, 1969.

[4] Fendt, Gene. For What May I Hope: Thinking with Kant and Kierkegaard. New York: Peter Lang, 1990.

[5] Freud, Sigmund. The Future of an Illusion. Translated by W.D. RobsonScott, revised by James Strachey. Garden City, NY: Anchor Books, 1964.

[6] Frye, Northrop. Anatomy of Criticism. Princeton: Princeton University Press, 1957.

[7] Gödel, Kurt. Undecidable Theories. Amsterdam, 1953.

[8] Harmon, Gilbert. Moral Relativism and Moral Objectivity. Oxford: Blackwell, 1996.

[9] Hume, David. An Enquiry Concerning Human Understanding. Edited by P. H. Nidditch and L. A. SelbyBigge. Oxford: Clarendon, 1975.

[10] James, William. The Will to Believe, Human Immortality, and Other Essays on Popular Philosophy. Mineola, NY: Dover Books, 1956.

[11] Kant, Immanuel. The Critique of Pure Reason. Translated by Norman Kemp Smith. London: MacMillan, 1933.

[12]_. The Critique of Practical Reason. Translated by Lewis White Beck. Indianapolis: LLA, 1956.

[13] _ _ The Critique of Judgment. Translated by Werner S. Pluhar. Indianapolis: Hackett, 1987.

[14] Lee, Desmond, ed. Wittgenstein's Lectures: Cambridge, 193032. London: Basil Blackwell, 1979.

[15] Lem, Stanislaw. Imaginary Magnitudes. Translated by Marc E. Heine. New York: Harcourt Brace Jovanovich, 1981.

[16] Locke, John. An Essay Concerning Human Understanding. Edited by Alexander Campbell Fraser. New York: Dover, 1959.

[17] Lynch, Michael P., ed. The Nature of Truth. Cambridge: MIT Press, 2001.

[18] Lyotard, JeanFrancois. The differend: Phrases in Dispute. Translated by Georges Van Den Abbeele. Minneapolis: University of Minnesota Press, 1988.

[19] Milbank, Alison. Chesterton and Tolkien as Theologians: The Fantasy of the Real. London: $\mathrm{T}$ and $\mathrm{T}$ Clark: 2007.

[20] Monk, Ray. Ludwig Wittgenstein: The Duty of Genius. New York: Macmillan, 1990.

[21] Moore, G.E. Principia Ethica. Cambridge: Cambridge University Press, 1903.

[22] Plato. Meno. Translated by W.R.M. Lamb. Cambridge, MA: Harvard University Press, 1967.

[23] _ _ Phaedrus. Translated by Harold N. Fowler. Cambridge, MA: Harvard University Press, 1925.

[24] Rhees, Rush. Recollections of Wittgenstein. Oxford: Oxford University Press, 1984.

[25] Rozema, David. "Tractatus LogicoPhilosophicus: A 'poem' by Ludwig Wittgenstein." Journal of the History of Ideas, Vol. 23 No. 2 (April 2002): 345363.

[26] Santayana, George. Winds of Doctrine: Studies in Contemporary Opinion. New York: Scribner's, 1913.

[27] Smith, Barbara Herrnstein. Contingencies of Value: alternative perspectives for critical theory. Cambridge: Harvard University Press, 1988.

[28] Tarski, Alfred. Undecidable Theories. Amsterdam: North Holland Publishing Co., 1953.

[29]___ "The Semantic Conception of Truth and the Foundations of Semantics." In The Nature of Truth, edited by Michael P. Lynch. Cambridge: MIT Press, 2001.

[30] Whitman, Walt. Song of Myself. 1855.

[31] Wiggins, David. Needs, Values, Truth: essays in the philosophy of value. New York: Blackwell, 1987.

[32] Wittgenstein, Ludwig. Tractatus LogicoPhilosophiccus. Translated by D. F. Pears and B. F. McGuinness. London: Routledge \& Kegan Paul, 1961.

[33]Zaidman, Louise Bruit, and Pauline Schmitt Pantel. Religion in the Ancient Greek City. Translated by Paul Cartledge. Cambridge: Cambridge University Press, 1992. 